\title{
Induction of secondary metabolites on nanoparticles stress in callus culture of Artemisia annua L.
}

\author{
K. Fatima ${ }^{a}$ (D), S. R. Abbas*b (D), M. Zia ${ }^{a}$ (D), S. M. Sabir C (D), R. T. Khan ${ }^{d}$ (D), A. A. Khan ${ }^{e}$ (D), \\ Z. Hassan ${ }^{\text {(D) }}$ and R. Zaman ${ }^{\text {(1) }}$
}

\author{
aDepartment of Biotechnology, Quaid-e-Azam University Isalmabad, Pakistan \\ ${ }^{b}$ Department of Biological Sciences, Hunza Campus, Karakorum International University Gilgit, Pakistan \\ 'Department of Chemistry, University of Poonch, Rawalakot, Pakistan \\ ${ }^{\mathrm{d} D e p a r t m e n t ~ o f ~ B o t a n y, ~ U n i v e r s i t y ~ o f ~ A z a d ~ J a m m u ~ a n d ~ K a s h m i r, ~ P a k i s t a n ~}$ \\ ${ }^{\mathrm{e}}$ College of Agriculture, Bahauddin Zakariya University, Bahadur Sub Campus Layyah, Pakistan \\ fDepartment of Biochemistry, University of Haripur, Pakistan \\ *e-mail: dr.syedrizwan@kiu.edu.pk
}

Received: January 13, 2020 - Accepted: April 02, 2020 - Distributed: May 31, 2021

(With 15 figures)

\begin{abstract}
Nanoparticles are known bio elicitors in plant biotechnology. Different concentrations of $\mathrm{ZnO}, \mathrm{CuO}$ and $\mathrm{CoO}$ nanoparticles were used for the enhanced accumulation of secondary metabolites and antioxidant activities in the callus derived from root, shoot and leaf of Artemisia annua L. Biomass of callus was somehow affected on high concentrations of Nps. Phenolic content was observed maximum $(60 \mu \mathrm{g})$ in shoot callus at $0.1 \mathrm{mg} / \mathrm{l}$ of CuONps. Total antioxidant activity was observed maximum $(33 \mu \mathrm{g})$ in root callus at $0.1 \mathrm{mg} / \mathrm{l}$ of $\mathrm{ZnOnps}$. Total reducing power maximum $(33 \mu \mathrm{g})$ was observed in root callus at concentration of $0.05 \mathrm{mg} / \mathrm{l}$ of CoONps. Maximum radical scavenging activity was observed in shoot callus at $0.05 \mathrm{mg} / \mathrm{l}$ of ZnONps. Rutin gallic acid and caffic acid were also determined in most of the samples by HPLC. The study concludes that different Nps have positive effect on the induction of secondary metabolites in A.annua plant.
\end{abstract}

Keywords: nanoparticles, Artemisia annua L., callus, HPLC, antioxidant activity, total reducing power.

\section{Indução de metabólitos secundários no estresse de nanopartículas em cultura de calos de Artemisiaannua $L$.}

\section{Resumo}

Nanopartículas são bio-elicitores conhecidos em biotecnologia de plantas. Diferentes concentrações de nanopartículas de $\mathrm{ZnO}, \mathrm{CuO}$ e $\mathrm{CoO}$ foram usadas para o acúmulo aumentado de metabólitos secundários e atividades antioxidantes no calo derivado da raiz, parte aérea e folha de Artemisiaannua L. A biomassa do calo foi de alguma forma afetada em altas concentrações de Nps. O conteúdo fenólico foi observado no máximo $(60 \mu \mathrm{g})$ no calo da parte aérea a $0,1 \mathrm{mg} / 1 \mathrm{de}$ CuONps. A atividade antioxidante total foi observada no máximo $(33 \mu \mathrm{g})$ no calo radicular a $0,1 \mathrm{mg} / 1 \mathrm{de} \mathrm{ZnOnps}$. O poder de redução total máximo $(33 \mu \mathrm{g})$ foi observado no calo radicular na concentração de $0,05 \mathrm{mg} / 1$ de CoONps. Atividade máxima de eliminação de radicais foi observada no calo da parte aérea a $0,05 \mathrm{mg} / 1$ de ZnONps. O ácido rutina-gálico e o ácido caffic também foram determinados na maioria das amostras por HPLC. O estudo conclui que diferentes Nps têm efeito positivo na indução de metabólitos secundários na planta de A.annua

Palavras-chave: nanopartículas, Artemisiaannua L., calo, HPLC, atividade antioxidante, potência redutora total.

\section{Introduction}

In renowned lecture, "There's Plenty of Room at the Bottom', Nobel laureate Richard P. Feynman introduced Nanotechnology for the first time in history. Following Feynman's idea of manipulation of matter at a very small scale, at molecular and atomic level, i.e. the nanoscale, radical developments have been done in fields of Chemistry, Biology, and Physics (Sanchez \&Sobolev, 2010). On the length scale, nanometer is the point where the smallest artificial devices come in contact with molecules and atoms of the natural world, owing to which nanotechnology is transforming industries and our lives.

Interaction of the nanoparticles and plants causes various physiological and morphological changes in plants and those changes depend on the characteristics of the nanoparticles. 
The chemical composition, reactivity, size and dose of NPs determine their effectiveness (Khodakovskaya et al., 2009). Scientists nowadays are busy in developing new techniques for plants to enhance their functions through Nps. NPs have distinctive chemical properties and they have tendency to make it happen (Giraldo et al., 2014).

Artemisia annua (annual wormowood) which is a medicinal herb belongs to Asteraceae family. It is naturally present in Asia, but is also cultivated and naturalized in different countries of Europe along with Italy where it is proposed as a replacement of traditional tobacco cultivation (Giraldo et al., 2014). This plant is widespread toward the northern parts of China where it famous by the name "quinghao" (green herb) and it has been utilized for the treatment of fever since 2000 years (Klayman, 1985).

In spite of the fact that artemisinin is a noteworthy bioactive segment present in the contemporary Chinese herbal preparations (tea), leaf flavonoids, also in tea, have demonstrated an array of biological activities and may synergize the impacts of artemisinin against cancer and malaria. The flavonoids in A.annua leaves have been associated with defeat of CYP450 enzymes accountable for changing the metabolism and absorption of artemisinin in the body, likewise they have been connected to a helpful immunomodulatory action in subjects aggrieved with chronic diseases and parasitic (Ferreira et al., 2010).

\section{Materials and Methods}

\subsection{Tested nanoparticles}

The three metallic nanoparticles were used in this study to evaluate the effect on the callus culture of Artemisia annua L. Nanoparticles include $\mathrm{ZnO}, \mathrm{CuO}$ and $\mathrm{CoO}$ nanoparticles. These nanoparticles were characterized by X-ray diffraction, UV-visible spectroscopy and Fourier transform infrared spectroscopy (FTIR) and scanning electron microscopy (SEM) analysis. The size of all NPs that were used was $<50 \mathrm{~nm}$.

\subsection{Media preparation for seed inoculation}

MS media was prepared for the inoculation of seeds. Seeds were sterilized under aseptic conditions by immersing in freshly prepared $0.1 \%$ mercuric chloride solution for 3-4 mins. Then the seeds were washed thrice with distilled water. Five seeds in each flask were inoculated and were placed in the growth room at $25{ }^{\circ} \mathrm{C}$. Seed germination was noticed after 1 week. The flasks were transferred to $16 \mathrm{hrs}$ photoperiod and kept for 4 weeks to obtain the full growth of the plantlets.

\subsection{Media preparation for Callus Induction}

For the inoculation of ex plant the media was prepared which contained nanoparticles and growth hormone NAA. The media was first divided in to fifteen flasks as there were five concentrations of each nanoparticle $(0.05$, $0.01,0.1,0.2$, and 0.3 ). Nanoparticles were weighed and added to the media in the flasks. Further two flasks were made from each concentration. The flasks were plugged and were autoclaved at $121^{\circ} \mathrm{C} 20$ minutes. After that flasks were kept for some time so that the media solidify again.

Plantlets were harvested from the flasks in aseptic conditions. The plants parts (root, shoot, and stem) were then cut with the surgical blade and inoculated in the nanoparticles media. Small nicks were made at the corners of the leaf for callus to sprout. It must be noted that the flasks were inoculated with one part of root, shoot and leaf i.e. each flasks containing a part of root shoot and leaf. The flasks were then labeled S, R and L indicating shoot, root and leaf in the flask. The flasks were then kept in growth room.

The flasks were kept under supervision. Induction of callus started after one and half week. But to achieve the full growth of the callus the flasks were kept for one month. After one month and few days callus was fully grown.

\subsection{Preparation of sample stock solution from crude extracts}

$4 \mathrm{mg}$ of dried plant extract was weighed in an eppendorf tube by using analytical balance and $1 \mathrm{ml}$ of dissolving solvent (DMSO, water or mixture of both) was added. The solution was then sonicated to ensure complete solubilization and some was stored while some of it was used.

\subsection{Determination of total Flavonoids}

$20 \mu 1$ of sample was taken in 96 well plates (microplates). $10 \mu 1$ Aluminium Chloride, $10 \mu 1$ Potassium acetate and $160 \mu \mathrm{l}$ of distilled water added respectively and incubated for 30 minutes.

\subsection{Determination of total Phenolic content}

$20 \mu \mathrm{L}$ of the test sample, positive control (gallic acid) and DMSO (negative control) were added to 96 well microplate, followed by addition of $90 \mu \mathrm{L}$ of FolinCiocalteu reagent and incubated for 5 minutes at room temperature. After incubation $90 \mu \mathrm{l}$ of sodium carbonate was added into the plate. Readings were taken at $630 \mathrm{~nm}$ wavelength on microplate reader.

\subsection{DPPH Free Radical Scavenging Assay}

$10 \mu \mathrm{l}$ of each test sample was pipetted in 96 well microplate. $190 \mu \mathrm{l}$ of DPPH reagent was mixed. Then reaction mixture was incubated for $1 \mathrm{hr}$ at $37^{\circ} \mathrm{C}$. Readings were measured at $517 \mathrm{~nm}$ wave length using microplate reader.

\subsection{Determination of Total Antioxidant Capacity (TAC)}

In an eppendorf tube $100 \mu \mathrm{l}$ of solution was mixed with $900 \mu 1$ reagent solution. The samples were then incubated at $95^{\circ} \mathrm{C}$ for 90 minutes in water bath. After incubation the reaction mixtures was cooled at room temperature. $200 \mu \mathrm{l}$ was transfered to a microplate for the optical density measurement. Absorbance was measured at $630 \mathrm{~nm}$ by using micro plate reader.

\subsection{Total Reducing Power Assay (TRP)}

$100 \mu \mathrm{l}$ of the test samples was taken in an Eppendorf tube and then $200 \mu \mathrm{l}$ of phosphate buffer and $250 \mu \mathrm{l}$ of $1 \%$ potassium ferricyanide solution were mixed. The reaction mixtures were then kept in water bath for $20 \mathrm{~min}$ at $50^{\circ} \mathrm{C}$ 
for incubation. After incubation, the mixtures were mixed with $200 \mu \mathrm{l}$ of $10 \%$ trichloroacetic acid. The resulting mixtures were then centrifuged at $3000 \mathrm{rpm}$ for $10 \mathrm{~min}$. $150 \mu \mathrm{l}$ of supernatant layer was taken from all the centrifuged samples and were poured in 96 well microplate and mixed with $50 \mu \mathrm{L}$ of $0.1 \%$ ferric chloride. Readings were taken at $630 \mathrm{~nm}$ by microplate reader.

\section{Results}

Objectives of the study were to determine the effect of $\mathrm{ZnO}, \mathrm{CuO}$ and $\mathrm{CoO}$ nanoparticles on the callus of explant of root, shoot and leaf of medicinally important Artemisia annua $L$. as well as biomass of the callus. The plant was grown in controlled conditions and then was harvested when the plantlets were grown. Then ex plants were taken from root shoot and leaf and inoculated in the nanoparticles containing media. Five different concentrations of each nanoparticle were used. Callus was harvested from the flasks were it was fully grown. Later phytochemical and antioxidant activities were performed.

\subsection{Effect of ZnO NPs on Callus Biomass of the Callus}

The callus was harvested from the flasks and its fresh weight was taken. Afterwards the callus was freeze dried and was weighed.

Maximum fresh weight of shoot callus was observed at concentration of $0.01 \mathrm{mg} / \mathrm{l}$ i.e. $1630 \mathrm{mgs}$ and as concentration of Nps increases biomass of the callus is decreasing. Callus of root and leaf has maximum biomass at concentration of $0.1 \mathrm{mg} / \mathrm{l}$ of $\mathrm{ZnONps}$ which is shown in Table 1 .

\subsection{Phytochemical Screening of Callus}

\subsubsection{Total Phenolic contents}

Total phenolic contents ( $\mu \mathrm{g}$ GAE/mgDW) were determined in the plant extracts treated with the different conditions of nanoparticles and results showed that maximum total phenolic contents were accumulated in the root callus at concentration of $0.1 \mathrm{mg} / 1 \mathrm{ZnO}$ nanoparticles shown in Figure 1.

\subsubsection{Total flavonoid contents}

Total flavonoid content ( $\mu \mathrm{g} \mathrm{QE} / \mathrm{mgDW}$ ) of the dried sample was by performing the phytochemical assays. According to the results obtained after performing total flavonoid activity, when the values are compared and the maximum flavonoids were observed in leaf at $0.05 \mathrm{mg} / \mathrm{l}$ in shoot at $0.01 \mathrm{mg} / 1$ and in root at $0.1 \mathrm{mg} / 1$ shown in Figure 2 .

\subsection{Antioxidant activity of Callus}

\subsubsection{Total antioxidant capacity}

Total antioxidant capacity results have shown maximum activity in root at $0.1 \mathrm{mg} / \mathrm{l}$ whereas in shoot at $0.01 \mathrm{mg} / 1$ shown in Figure 3.

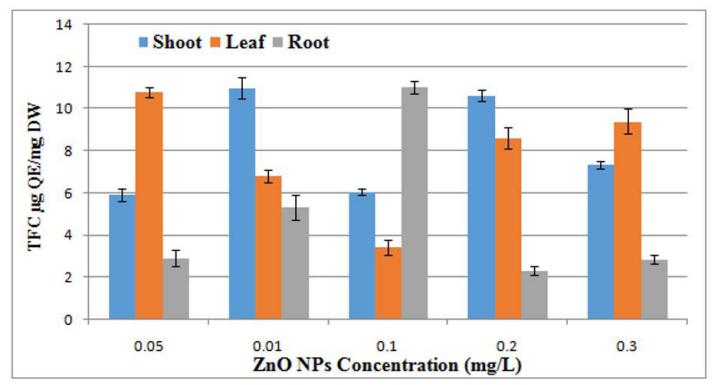

Figure1. Effect of $\mathrm{ZnO}$ NPs on total phenolic content of the Callus derived from Root, Shoot and Leaf of Artemisia annua $\mathrm{L}$.

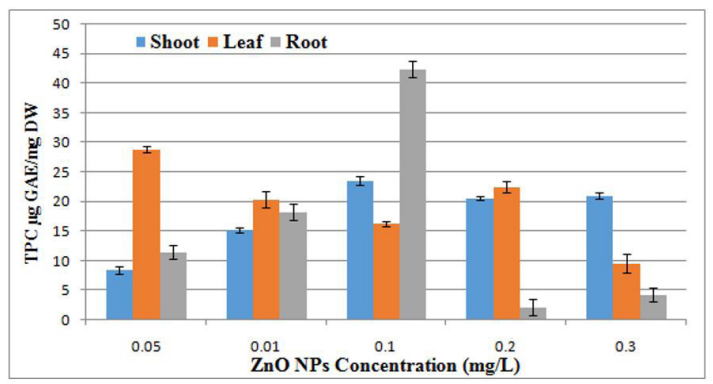

Figure 2. Effect of $\mathrm{ZnO}$ NPs on total flavanoid content of the Callus derived from Root, Shoot and leaf of Artemisia annua $\mathrm{L}$

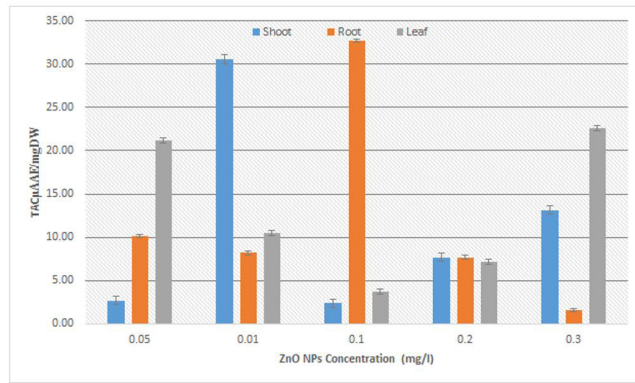

Figure 3. Total antioxidant activity of Root, Shoot and leaf callus ofArtemisiaannua L. against different concentrations of $\mathrm{ZnO}$ NPs

Table 1. Effect of ZnONps on the average fresh and dry weight of Aremisiaannua L. callus.

\begin{tabular}{|c|c|c|c|c|c|c|c|}
\hline \multirow{2}{*}{ S.no } & \multirow{2}{*}{ Conc mg/l } & \multicolumn{2}{|c|}{ Shoot Mgs } & \multicolumn{2}{|c|}{ Root mgs } & \multicolumn{2}{|c|}{ Leaf mgs } \\
\hline & & FW & DW & FW & DW & FW & DW \\
\hline 1 & 0.05 & 1630 & 42 & 760 & 26 & 760 & 47 \\
\hline 2 & 0.01 & 1140 & 83 & 3400 & 23 & 1450 & 340 \\
\hline 3 & 0.1 & 1400 & 77 & 3390 & 150 & 2310 & 180 \\
\hline 4 & 0.2 & 880 & 68 & 200 & 22 & 700 & 8 \\
\hline 5 & 0.3 & 660 & 76 & 280 & 29 & 108 & 18 \\
\hline
\end{tabular}




\subsubsection{Total reducing power}

According to the results of total reducing power assay, maximum activity was found in root at $0.1 \mathrm{mg} / 1$ and in shoot at $0.01 \mathrm{mg} / \mathrm{l}$. Whereas in leaf maximum activity is on $0.05 \mathrm{mg} / \mathrm{l}$ and $0.3 \mathrm{mg} / \mathrm{l}$ shown in Figure 4.

\subsection{DPPH radical scavenging activity}

DPPH radical scavenging activity was determined in the callus grown in the nanoparticles media and the results of each concentration were compared. The results have shown that the shoot callus at concentration of $0.05 \mathrm{mg} / 1$ and $0.01 \mathrm{mg} / 1$ has maximum radical scavenging activity. Whereas callus of leaf showed maximum radical scavenging activity at concentration of $0.1 \mathrm{mg} / 1$ and $0.2 \mathrm{mg} / \mathrm{l}$. This activity is not very prominent in the root callus as compared to shoot and leaf callus. (Figure 5).

\subsection{HPLC-DAD analysis}

HPLC analysis was used for quantitative analysis of the dried callus of $A$. annua. The peaks of HPLC were compared with UV absorption spectra. The results of HPLC quantitative profiling showed that maximum rutin and gallic acid in the leaf callus accumulate at $0.1 \mathrm{mg} / 1$ of $\mathrm{ZnO}$ nanoparticles which is $24.39 \mu \mathrm{g} / \mathrm{mg}$ dry weight and $21.27 \mu \mathrm{g} / \mathrm{mg}$ dry weight respectively. While caffic acid was present in highest amount at concentration of $0.05 \mathrm{mg} / 1$ of $\mathrm{ZnONps}$ and not determined at other concentrations in leaf callus. In the callus of root maximum amount of rutin and gallic were observed at concentrations of $0.05 \mathrm{mg} / 1$ and $0.1 \mathrm{mg} / \mathrm{l}$ of $\mathrm{Nps}$ respectively.

Maximum amount of rutin in the leaf callus was observed at concentration of $0.3 \mathrm{mg} / 1$ of $\mathrm{ZnONps}$ and that is $45.81 \mu \mathrm{g} / \mathrm{mg}$ dry weight. Highest amount of gallic acid and caffic acid is observed at concentration of $0.2 \mathrm{mg} / 1$ and $0.3 \mathrm{mg} / \mathrm{l}$ of $\mathrm{ZnONps}$ which is $14.92 \mu \mathrm{g} / \mathrm{mg}$ dry weight and $11.72 \mu \mathrm{g} / \mathrm{mg}$ dry weight respectively. Both were not determined at few other concentrations shown in Table 2.

\subsection{Effect of CuO NPs on Callus Biomass of the Callus}

Callus grown in the $\mathrm{Nps}$ of $\mathrm{CuO}$ was obtained and its fresh weight was taken. Later it was freeze dried and its dry weight was recorded. Maximum biomass of shoot callus was observed at concentration of $0.01 \mathrm{mg} / \mathrm{l}$ of $\mathrm{CuONps}$ which is $23600 \mathrm{mgs}$ and dry weight at $0.1 \mathrm{mg} / \mathrm{l}$. Callus of root has maximum biomass at $0.05 \mathrm{mg} / 1$ of $\mathrm{CuONps}$ and dry weight at $0.1 \mathrm{mg} / 1$ concentration which is $3590 \mathrm{mgs}$ and $447 \mathrm{mgs}$ respectively. Leaf callus has maximum biomass at concentration of 0.1 that is $4330 \mathrm{mgs}$. (Table 3 )

\subsection{Phytochemical screening of callus}

\subsubsection{Total flavonoid contents}

According to the results obtained after performing total flavonoid activities, the results have shown maximum flavonoids activity in leaf and root callus grown at concentration of $0.2 \mathrm{mg} / \mathrm{l}$ and $0.3 \mathrm{mg} / \mathrm{l}$ of $\mathrm{CuONps}$. (Figure 6)

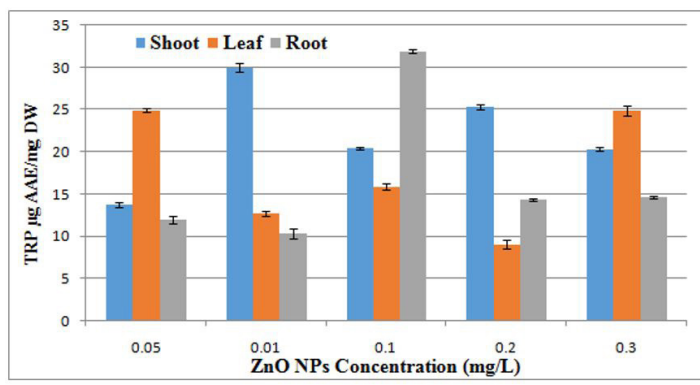

Figure 4. Total reducing power of Root, Shoot and leaf callus of Artemisia annua L. against different concentrations of $\mathrm{ZnO} \mathrm{NPS}$

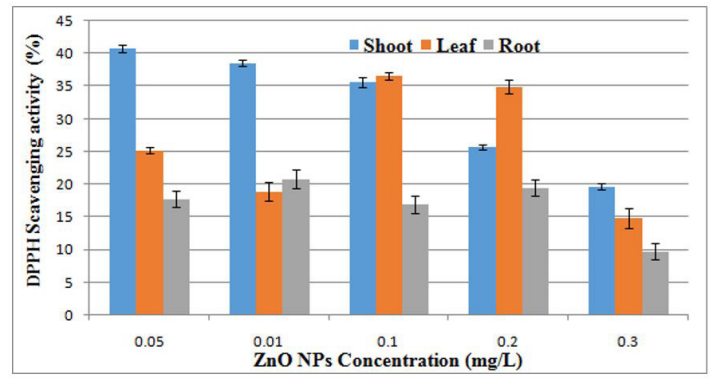

Figure 5. DPPH radical scavenging activity of Root, Shoot and Leaf callus of Artemisia annua L. against different concentrations of $\mathrm{ZnO}$ NPs

Table 2. HPLC-DAD analysis of callus of Artemisia annua L. derived from root shoot and root grown in different concentrations of $\mathrm{ZnONps}$.

\begin{tabular}{|c|c|c|c|c|c|c|c|c|c|c|}
\hline \multirow[b]{2}{*}{ S.n o } & \multirow[b]{2}{*}{$\begin{array}{l}\text { Conc } \\
\mathrm{mg} / \mathrm{l}\end{array}$} & \multicolumn{3}{|c|}{ Shoot } & \multicolumn{3}{|c|}{ Root } & \multicolumn{3}{|c|}{ Leaf } \\
\hline & & $\begin{array}{c}\text { Rutin } \\
\mu g / m g \\
\text { dw }\end{array}$ & $\begin{array}{c}\text { Gallic } \\
\mu \mathrm{g} / \mathrm{mg} \\
\mathrm{dw}\end{array}$ & $\begin{array}{c}\text { Caffic } \\
\mu \mathrm{g} / \mathrm{mg} \\
\mathrm{dw}\end{array}$ & $\begin{array}{c}\text { Rutin } \mu g / \\
\text { mg dw }\end{array}$ & $\begin{array}{c}\text { Gallic } \\
\mu \mathrm{g} / \mathrm{mg} \\
\mathrm{dw}\end{array}$ & $\begin{array}{c}\text { Caffic } \\
\mu \mathrm{g} / \mathrm{mg} \\
\mathrm{dw}\end{array}$ & $\begin{array}{c}\text { Rutin } \\
\mu \mathrm{g} / \mathrm{mg} \\
\mathrm{dw}\end{array}$ & $\begin{array}{c}\text { Gallic } \\
\mu \mathrm{g} / \mathrm{mg} \\
\mathrm{dw}\end{array}$ & $\begin{array}{c}\text { Caffic } \\
\mu g / m g \\
d w\end{array}$ \\
\hline 1 & 0.05 & 22.67 & 6.63 & 9.03 & 40.86 & 6.11 & 10.08 & 27.97 & 8.84 & 9.14 \\
\hline 2 & 0.01 & 20.12 & 8.12 & ND & 8.42 & ND & ND & 11.42 & ND & ND \\
\hline 3 & 0.1 & 25.39 & 21.27 & 8.21 & 37.98 & 7.46 & ND & 10.69 & 8.28 & ND \\
\hline 4 & 0.2 & 11.26 & 5.92 & ND & 19.28 & ND & ND & 31.08 & 14.92 & 9.01 \\
\hline 5 & 0.3 & 9.5 & 9.47 & ND & 44.87 & ND & ND & 45.81 & 13.86 & 11.72 \\
\hline
\end{tabular}

ND: not detected 
Table 3. Effect of CuONps on the average fresh and dry weight of Aremisiaannua L. callus.

\begin{tabular}{|c|c|c|c|c|c|c|c|}
\hline \multirow{2}{*}{ S.no } & \multirow{2}{*}{ Conc mg/l } & \multicolumn{2}{|c|}{ Shoot mgs } & \multicolumn{2}{|c|}{ Root mgs } & \multicolumn{2}{|c|}{ Leaf mgs } \\
\hline & & FW & DW & FW & DW & FW & DW \\
\hline 1 & 0.05 & 2080 & 200 & 3590 & 230 & 2900 & 1820 \\
\hline 2 & 0.01 & 23600 & 166 & 140 & 100 & 330 & 7.6 \\
\hline 3 & 0.1 & 2820 & 215 & 3586 & 447 & 4330 & 271 \\
\hline 4 & 0.2 & 1000 & 199 & 2020 & 133 & 910 & 800 \\
\hline 5 & 0.3 & 1550 & 147 & 2470 & 198 & 2590 & 158 \\
\hline
\end{tabular}

\subsubsection{Total Phenolic contents}

The total phenol content ( $\mu \mathrm{g}(\mathrm{GAE}) / \mathrm{mg} \mathrm{DW})$ of Artemisia annua L. callus was checked using the modified Folin-Ciocalteu assay. It is sensitive to phenol and polyphenol units and other electron donating antioxidants. After performing total phenolic activities, the trend has shown $62 \mu \mathrm{g}$ maximum phenolic content in callus at concentration of $0.01 \mathrm{CuONps}$ followed by $40 \mu \mathrm{g}$ in leaf at concentration of $0.2 \mathrm{mg} / 1$ of CuoNps. (Figure 7).

\subsection{Antioxidant Activity of Callus}

\subsubsection{Total antioxidant capacity}

Total antioxidant assay esults have shown that the maximum activity is observed in leaf callus at concentration of $0.2 \mathrm{mg} / 1$ of CuONps followed by shoot callus at $0.05 \mathrm{mg} / \mathrm{l}$. (Figure 8).

\subsubsection{Total reducing power}

According to the results of total reducing power assay the activity was maximum in root callus at concentrations of $0.3 \mathrm{mg} / 1$ and $0.2 \mathrm{mg} / 1 \mathrm{CuONps}$ followed by shoot callus at $0.3 \mathrm{mg} / \mathrm{l}$ and $0.05 \mathrm{mg} / \mathrm{l}$. (Figure 9)

\subsection{DPPH activity}

The DPPH radical scavenging assay is an easy rapid and sensitive method for the antioxidant screening of plant extracts. It is one of the shortest available tests to examine the overall hydrogen/electron donating activity of single antioxidants and health promoting dietary antioxidant supplements.

In this experiment maximum DPPH scavenging activity was observed in callus derived from leaf at concentration of $0.01 \mathrm{mg} / 1 \mathrm{CuONps}$ and the free radical scavenging activity is $52 \%$. On second is root callus that is $44 \%$ at concentration of $0.2 \mathrm{mg} / 1$ of CuoNps. (Figure 10)

\subsection{HPLC-DAD analysis}

Reverse phase analysis technique was used for the quantitative analysis of Artemisia annua L. callus grown in different concentrations of $\mathrm{CuO}$ nanoparticles. . The results of HPLC quantitative profiling showed that maximum rutin and gallic acid in the shoot callus at concentration of $0.01 \mathrm{mg} / 1$ and $0.1 \mathrm{mg} / 1$ which is $19.69 \mu \mathrm{g} /$ $\mathrm{mg} \mathrm{dw}$ and $10.18 \mu \mathrm{g} / \mathrm{mg} \mathrm{dw}$ respectively. While caffic acid was shown maximum at concentration of $0.3 \mathrm{mg} / 1$ of $\mathrm{CuONps}$ which is $10.79 \mu \mathrm{g} / \mathrm{mg} \mathrm{dw}$. In callus derived from root rutin and gallic acid were observed maximum at $0.3 \mathrm{mg} / 1$ and $0.1 \mathrm{mg} / 1$ of CuONps which is $21.76 \mu \mathrm{g} / \mathrm{mg}$ $\mathrm{dw}$ and $11.71 \mu \mathrm{g} / \mathrm{mg}$ dw. Caffic acid was not determined. In the callus of leaf maximum rutin and gallic acid were observed maximum at $0.1 \mathrm{mg} / \mathrm{l}$ of CuONps. Caffic acid was only determined at concentration of $0.1 \mathrm{mg} / 1$ which was $9.72 \mu \mathrm{g} / \mathrm{mg} \mathrm{dw}$. (Table 4)

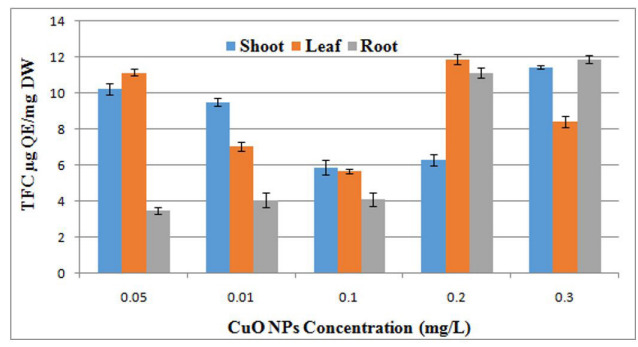

Figure 6. Effect of different concentrations of $\mathrm{CuONps}$ on total flavonoid content of $A$. аппиа callus derived from shoot and root and leaf

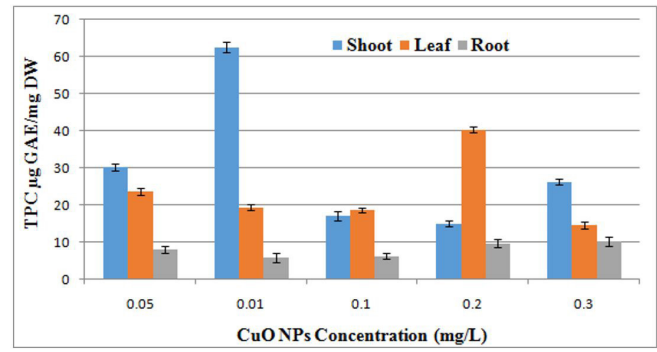

Figure 7. Effect of different concentrations of $\mathrm{CuONps}$ on total phenolic content of $A$. annua callus derived from shoot and root and leaf

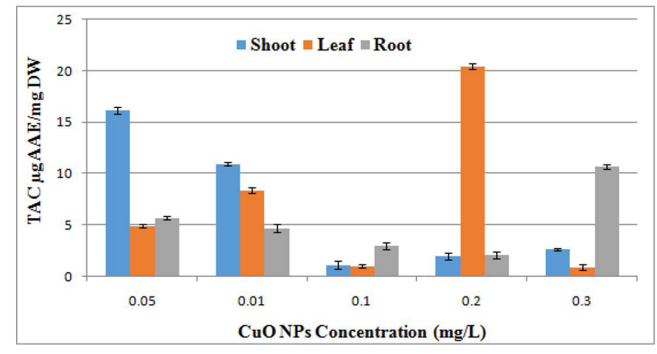

Figure 8. Total antioxidant activity of root, shoot and leaf callus against different concentrations of CuONps.

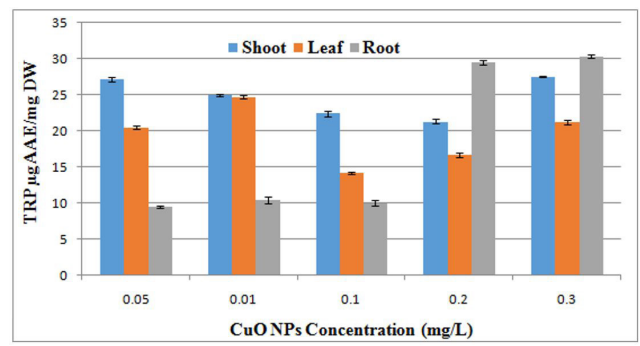

Figure 9. Impact of different concentrations of $\mathrm{CuONps}$ on total reducing power activity of $A$. annua callus derived from root shoot and leaf. 


\subsection{Effect of CoO NPs on Callus Biomass of the Callus}

Callus grown at different concentrations of $\mathrm{CoO}$ nanoparticles was harvested from flasks and its fresh weight weight was taken. After taking fresh weight the callus was then kept for freeze drying. Dry weight of the callus the callus was taken afterwards. Maximum fresh weight of shoot was noted at concentration of $0.05 \mathrm{mg} / 1$ of CoONps and maximum dry weight at $0.1 \mathrm{mg} / 1$ of CoONps. Maximum fresh and dry weight of root callus was at concentration of $0.1 \mathrm{mg} / 1$ of Nps. Biomass of leaf callus obtained on concentration of $0.3 \mathrm{mg} / 1$ of $\mathrm{CoONps}$ was maximum. (Table 5)

\subsection{Phytochemical Screening of Callus}

\subsubsection{Total flavonoid contents}

After performing photochemical assays of the plat extract the results showed that maximum flavonoid activity was on the concentration of $0.05 \mathrm{mg} / \mathrm{l}$ of $\mathrm{CoO}$ nanoparticles and it was $15 \mu \mathrm{g}$. (Figure 11).

\subsubsection{Total Phenolic contents}

When the phenolic content of $A$. annua was investigated through the photochemical test the results showed that maximum phenolic activity was in leaf callus at concentration of $0.2 \mathrm{mg} / 1$ of CoONps. It was followed by shoot callus at concentration of $0.05 \mathrm{mg} / 1$ of CoONps. (Figure 12).

\subsection{Antioxidant Activity of Callus}

\subsubsection{Total antioxidant capacity}

Total antioxidant capacity was found maximum at concentration of $0.2 \mathrm{mg} / \mathrm{l}$ of CoONps in the root callus. (Figure 13).

\subsubsection{Total reducing power}

According to the results total reducing power was found maximum at concentration of $0.05 \mathrm{mg} / \mathrm{l}$ in callus of root followed by callus of leaf at the same concentration. (Figure 14)

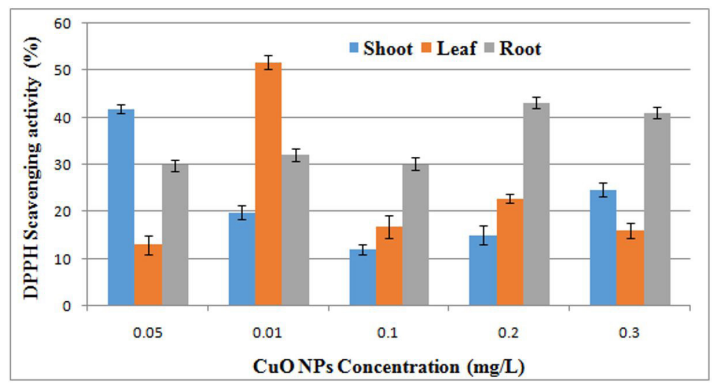

Figure 10. Effect of different concentrations of $\mathrm{CuONps}$ on DPPH radical scavenging activity of A. апnиa callus derived from root shoot and leaf

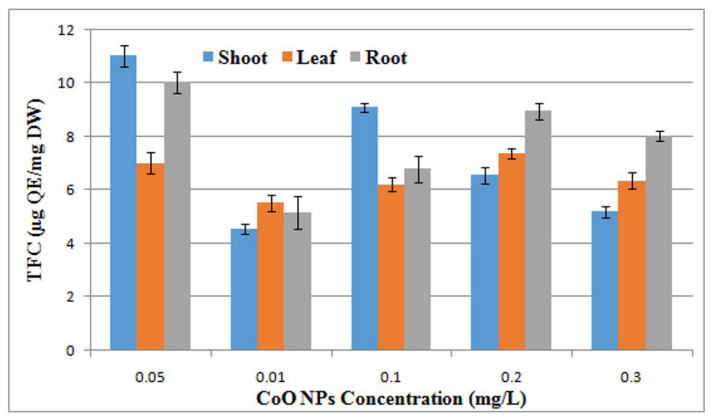

Figure 11. Effect of different concentrations of CoONps on total flavonoid content of $A$. аппиа callus derived from shoot and root and leaf

Table 4. HPLC-DAD analysis of callus of Artemisia annua L. derived from root shoot and root grown in different concentrations of $\mathrm{CuONps}$.

\begin{tabular}{|c|c|c|c|c|c|c|c|c|c|c|}
\hline \multirow[b]{2}{*}{$\begin{array}{l}\text { S. } \\
\text { no }\end{array}$} & \multirow[b]{2}{*}{$\begin{array}{c}\text { Con c } \\
\mathrm{mg} / \mathrm{l}\end{array}$} & \multicolumn{3}{|c|}{ Shoot } & \multicolumn{3}{|c|}{ Root } & \multicolumn{3}{|c|}{ Leaf } \\
\hline & & $\begin{array}{c}\text { Rutin } \\
\mu \mathrm{g} / 10 \\
0 \mathrm{mg} \mathbf{d w}\end{array}$ & $\begin{array}{c}\text { Gallic } \\
\mu \mathrm{g} / 100 \\
\mathrm{mg} \mathrm{dw}\end{array}$ & $\begin{array}{l}\text { Caffic } \\
\mu g 100 / \\
\text { mg dw }\end{array}$ & $\begin{array}{c}\text { Rutin } \\
\mu g / 100 \\
m g ~ d w\end{array}$ & $\begin{array}{l}\text { Gallic } \\
\mu \mathrm{g} 100 / \\
\mathrm{mg} \mathrm{dw}\end{array}$ & $\begin{array}{c}\text { Caffic } \\
\mu g / 100 \\
m g ~ d w\end{array}$ & $\begin{array}{c}\text { Rutin } \\
\mu g / 100 \\
\text { mg dw }\end{array}$ & $\begin{array}{c}\text { Gallic } \\
\mu \mathrm{g} / 100 \\
\mathrm{mg} \mathrm{dw}\end{array}$ & $\begin{array}{l}\text { Caffic } \\
\mu g / 100 \\
\text { mg dw }\end{array}$ \\
\hline 1 & 0.05 & 18.72 & 6.68 & 8.63 & 17.11 & 4.59 & ND & 14.44 & 7.84 & ND \\
\hline 2 & 0.01 & 19.69 & 6.01 & ND & 13.12 & ND & ND & 8.41 & ND & ND \\
\hline 3 & 0.1 & 11.63 & 10.18 & 8.47 & 11.23 & 11.71 & ND & 19.77 & 10.74 & 9.72 \\
\hline 4 & 0.2 & 17.45 & 9.93 & 10.07 & 13.36 & 7.1 & ND & 18.53 & 6.43 & ND \\
\hline 5 & 0.3 & 10.12 & 5.25 & 10.79 & 21.76 & 7.95 & ND & 11.96 & 7.57 & ND \\
\hline
\end{tabular}

ND: not detected

Table 5. Effect of CoONps on the average fresh and dry weight of Aremisiaannua L. callus.

\begin{tabular}{|c|c|c|c|c|c|c|c|}
\hline \multirow{2}{*}{ S.no } & \multirow{2}{*}{ Conc mg/l } & \multicolumn{2}{|c|}{ Shoot mgs } & \multicolumn{2}{|c|}{ Root Mgs } & \multicolumn{2}{|c|}{ Leaf mgs } \\
\hline & & FW & DW & FW & DW & FW & DW \\
\hline 1 & 0.05 & 6720 & 198 & 3590 & 238 & 1070 & 114 \\
\hline 2 & 0.01 & 5720 & 86 & 2930 & 191 & 2550 & 238 \\
\hline 3 & 0.1 & 2550 & 238 & 5600 & 370 & 1450 & 88 \\
\hline 4 & 0.2 & 1930 & 153 & 3390 & 239 & 1410 & 63 \\
\hline 5 & 0.3 & 1450 & 127 & 2653 & 176 & 4080 & 316 \\
\hline
\end{tabular}




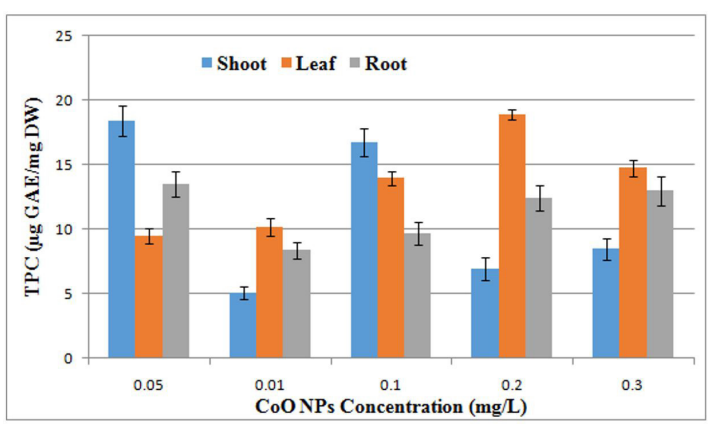

Figure 12. Effect of different concentrations of CoONps on total phenolic content of $A$. annua callus derived from shoot and root and leaf

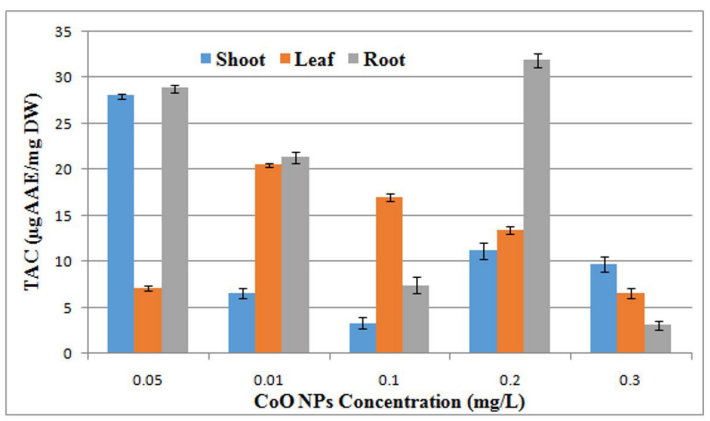

Figure 13. Effect of different concentrations of CoONps on total antioxidant activity of $A$. апnи shoot and root and leaf

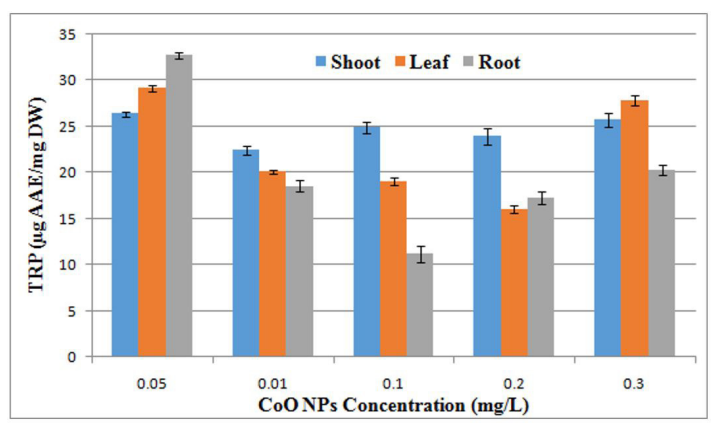

Figure 14. Effect of different concentrations of CoONps on total reducing power activity of $A$. annua callus derived from shoot and root and leaf

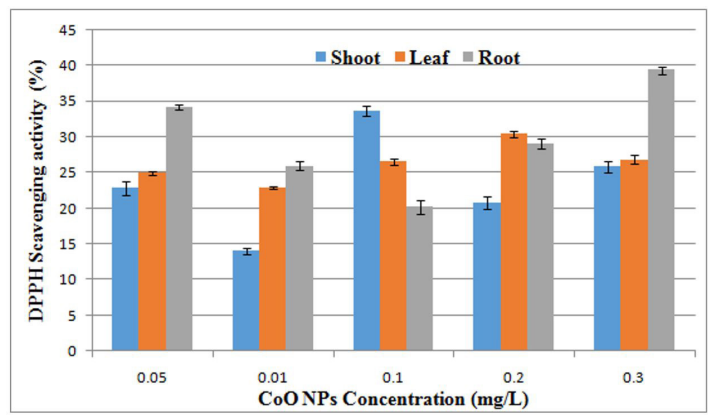

Figure 15. Effect of different concentrations of CoONps on DPPH radical scavenging activity of $A$. апnиa callus derived from shoot and root and leaf

Table 6. HPLC-DAD analysis of callus of Artemisia annua L. derived from root shoot and root grown in different concentrations of $\mathrm{CuONps}$.

\begin{tabular}{|c|c|c|c|c|c|c|c|c|c|c|}
\hline \multirow[b]{2}{*}{ S. no } & \multirow[b]{2}{*}{$\begin{array}{c}\text { Conc } \\
\mathrm{mg} / \mathrm{l}\end{array}$} & \multicolumn{3}{|c|}{ Shoot } & \multicolumn{3}{|c|}{ Root } & \multicolumn{3}{|c|}{ Leaf } \\
\hline & & $\begin{array}{l}\text { Rutin } \\
\mu \mathrm{g} / 100 \\
\mathrm{mg} \mathrm{dw}\end{array}$ & $\begin{array}{c}\text { Gallic } \\
\mu \mathrm{g} / 100 \\
\mathrm{mg} \mathrm{dw}\end{array}$ & $\begin{array}{c}\text { Caffic } \\
\mu \mathrm{g} / 100 \\
\mathrm{mg} \mathrm{dw}\end{array}$ & $\begin{array}{c}\text { Rutin } \\
\mu \mathrm{g} / 100 \\
\mathrm{mg} \mathrm{dw}\end{array}$ & $\begin{array}{c}\text { Gallic } \\
\mu \mathrm{g} / 100 \\
\mathrm{mg} \mathrm{dw}\end{array}$ & $\begin{array}{c}\text { Caffic } \\
\mu \mathrm{g} / 100 \\
\mathrm{mg} \mathrm{dw}\end{array}$ & $\begin{array}{l}\text { Rutin } \\
\mu \mathrm{g} / 100 \\
\mathrm{mg} \mathbf{d w}\end{array}$ & $\begin{array}{c}\text { Gallic } \\
\mu \mathrm{g} / 100 \\
\mathrm{mg} \mathrm{dw}\end{array}$ & $\begin{array}{c}\text { Caffic } \\
\mu \mathrm{g} / 100 \\
\mathrm{mg} \mathrm{dw}\end{array}$ \\
\hline 1 & 0.05 & 12.92 & 5.63 & ND & 18.08 & 6.82 & ND & 10.74 & ND & 10.59 \\
\hline 2 & 0.01 & 11.64 & 5.7 & ND & 15.57 & 6.77 & ND & 9.67 & 7.81 & ND \\
\hline 3 & 0.1 & 23.56 & 6.7 & 10.01 & 16.07 & 8.58 & 9.1 & 15.17 & ND & 9.72 \\
\hline 4 & 0.2 & 17.2 & ND & ND & 16.45 & 7.62 & 8.89 & 9.64 & 5.79 & ND \\
\hline 5 & 0.3 & 32.19 & 14.05 & ND & 36.26 & 27.43 & ND & 24.58 & ND & ND \\
\hline
\end{tabular}

\subsection{DPPH radical scavenging activity}

According to the results DPPH radical scavenging activity was found maximum in the callus of root at $0.3 \mathrm{mg} / 1$ of CoONps. (Figure 15).

\subsection{HPLC}

The results of HPLC quatitative profiling of the dried callus sample indicated the presence of rutin, gallic acid and caffic acid. Maximum rutin was found in the callus of $\operatorname{root}(36.26 \mu \mathrm{g} / \mathrm{mg} \mathrm{dw})$. Amount of gallic acid was found maximum $(27.43 \mu \mathrm{g} / \mathrm{mg} \mathrm{dw})$ in root callus. Caffic acid was found maximum $(10.59 \mu \mathrm{g} / \mathrm{mg} \mathrm{dw})$ in leaf callus. (Table 6)

\section{Discussion}

Field of nanosciences has gained much attention in the last decade. The major development of nanotechnology is the application of nanoparticles in biological sciences (Liu, 2006).

Nanotechnology has also permitted advanced research in areas including biotechnology and agriculture to improve crop yield, therefore using nanoparticles as fertilizers. Nanoparticles possess features that are beneficial to the crop plants. Nps can be fruitful in a way that they play role in the release of chemical fertilizer according to the 
demand hence enhancing the target delivery of fertilizers and plant growth (DeRosa et al., 2010). According to the previous reports engineered nanoparticles in general and metal nanoparticles in particular affects plant's morphology and physiology depending on the properties of nanoparticles.

Among all the most recent technologies nanotechnology resides at a primary position in revolutionizing crop production and food industry. The progress of nanomaterials like nanofertilizers and other nanodevices can bring in innovative applications in agriculture and plant biotechnology (Scrinis\& Lyons, 2007). Advancement in nanotechnology may facilitate and promote farming technologies, genetically modified crops and pesticides. It further permits the advanced research like conversion of agricultural waste in to useful products through nano bioprocessing and treatments of plants by using different nanocides (Roco, 2003). The most innovative technology of nanosciences in agriculture, that the nanodevices make the agricultural system 'smart'. These kinds of devices are able to respond to different situation and take correct action by controlled and targeted delivery of the chemical. Development of targeted delivery system can deal with the biological barriers to huge extent. (Nair et al., 2010).

Artemisia annua is a medicinal plant having number of active compounds like flavonoids, phenols, triterpenoids, sesquiterpenoids and aliphatic compounds in different parts of the plants. Some of these bioactive compounds are claimed to be the part of traditional system of medicines. Components like artemisnin are already being used as a potent antimalarial drug. Further invitro studies of other bioactive compounds identified may give new therapeutics of huge commercial importance (Bhakuni et al., 2001). The increased production of secondary metabolites having such unique properties is usually done by exposure of the plants to different elicitors or signal molecules (Zhao et al.,2005). Nanoparticles have the tendency to use them as effective elicitors in plants to enhance the production of secondary metabolites (Fakruddin et al., 2012). The elicitation potential of silver nanoparticles was highlighted by Zhang et al. (2013) for enhancement of the production of secondary metabolites in plants. $\mathrm{Ag}-\mathrm{SiO} 2$ core-shell nanoparticles (AgNPs) were used for the elicitation of artemisinin content in hairy root culture of A. annua. The production of artemisinin was enhanced from $1.67 \mathrm{mg} / \mathrm{g}$ dry wt to $2.86 \mathrm{mg} / \mathrm{g}$ dry wt by the stimulation of silver nanoparticles. The artemisinin content was enhanced due to the oxidative stress induced by silver Nps which resulted in lipid peroxidation and enhanced activities of catalase (Zhang et al., 2013). All these studies aim to increase the production of secondary metabolites as they are produced in very less amount naturally. Results of my studies are according to these experiments.

In a study conducted for the enhanced production of secondary metabolites in the callus culture Prunella vulgaris L. different ratios of gold and silver nanoparticles with NAA were used. The results showed that silver nanoparticles silver nanoparticles without NAA produced higher biomass in log phase. $\mathrm{AgAu}(1: 3)$ and AuNPs increased the proline content, superoxide dismutase and peroxidase enzymes in callus cultures. Silver and gold Nps (1:3) including NAA promoted maximum accumulation of flavonoid and phenolic content (Fazal et al., 2016).

In many plants nanoparticles are used as elicitors to enhance the production of secondary metabolites. Glycyrrhiza glabra plant seedlings were treated with nanopartricles of $\mathrm{CuO}, \mathrm{ZnO}$ and bulk $\mathrm{Zn}$ and $\mathrm{CuO}$. The results showed an increase in the contents of glycyrrhizin, proline content, total phenolic compounds and anthocyanins. Comparisons of results also showed that nano particles of $\mathrm{CuO}$ and $\mathrm{ZnO}$ have greater effect as compared to the bulk size $\mathrm{CuO}$ and $\mathrm{ZnO}$ particles (Oloumi et al., 2015). Results of current study are related to this study.

The objective of the current study was to enhance the secondary metabolites on nanoparticles stress in callus culture of medicinally important Artemisia aпnиа L. The nanoparticles used were $\mathrm{ZnO}, \mathrm{CuO}$ and $\mathrm{CoONps}$.

Previous studies have shown that nanoparticles like zinc oxide, cerium oxide, and silver NPs were deposited on the organelles of the cells which induced stress to cell which resulted induction of oxidative stress signaling (Buzea, Pacheco, \& Robbie, 2007). In another experiment carried out by inducing stress through cerium oxide nanoparticles in the different plant cell cultures showed that nanoparticles have potential to induce intracellular oxidative stress (Horie et al., 2011). Helaly et al.reported that the incorporation of $\mathrm{ZnO}$ nanoparticles particles on growth media at different concentrations the callus growth was decreased but total proline as well as SOD, CAT and POX activities considerably increased (Helaly et al., 2014). Presence of different metallic and non metallic nanoparticles in the growth medium induces stress which activates the antioxidant defense system in plants which results in to the enhanced production of secondary metabolites. Growth of the callus may decrease but the enzyme activity increases as reported in the above mentioned experiments.

The reason for taking different ex plants was the reported different amounts of secondary metabolites in different parts of the parts. Artemisia annua L. leaves has highest amount of flavanoids reported (Ferreira et al., 2010). But in the experiment callus of root and shoot also had a considerable amount of phenolic and flavonoid content.

Average fresh weight was found to be maximum at concentrations of $0.05 \mathrm{mg} / \mathrm{l} \mathrm{CoO} \mathrm{NPs} \mathrm{and} 0.01 \mathrm{mg} / 1$ of CoONps as compared to the other concentrations. The increase in biomass at certain concentration suggests the optimum dose limit for the growth of Artemisia annua L. callus. However, decrease in biomass beyond this concentration may be the toxic effect of the nanoparticles. Flavonoids and phenolics are one of the most important secondary metabolites of Artemisia annua L. Total flavonoid and phenolic contents were determined and results have shown that the callus of leaf at conc of $0.2 \mathrm{mg} / \mathrm{l}$ and callus of root at $0.3 \mathrm{mg} / 1$ accumulated maximum flavonoid contents indicating the elicitation of secondary metabolites production in the presence of $\mathrm{CuO}$ nanoparticles. Accumulation of $\mathrm{CuO}$ particles can reduce growth but enhances increased lipid 
peroxidation and oxidized glutathione in Triticum aestivum (Dimkpa et al., 2012). Along with the total flavonoid and phenols another compounds like rutin, caffic acid and gallic acid were detected in HPLC.

In another experiment conducted Co nanoparticles were used to enhance the production of medicinally important artemisinin. For this purpose the expression of genes SQS and DBR2 genes were amplified by qRT-PCR, then by HPLC artemisinin content was measured under the elicitation of nanaoprticles of cobalt in A annua cell suspension culture. The results showed that production of artemisinin was 2.25 folds more (Ghasemi et al., 2015).

Different concentrations of silver nanoparticles in Brassica juncea L. seedlings increased root and shoot length and induced the activities of specific antioxidant enzymes. proline content was decreased which confirmed the improvement in antioxidant status in the seedlings (Sharma et al., 2012).

\section{Callus Induction}

Micro propagation is a very useful method which is exploited positively for medicinal purposes in many plants. It can be useful in economical point of view for production of medicinal compounds. Callus is an undifferentiated mass of cells which is proved useful in plant biotechnology (Jattana et al., 2008). Artemisia annua $\mathrm{L}$. is a herb with medicinal properties. Induction of callus is one of the options to enhance the production of phenolic and flavonoid content.

The outcomes of the current study show that growth of callus was not very much even though NAA was also added. Results are in accordance with Helaly et al. as he described that growth of callus of banana plant was decreased due to toxicity of nanoparticles but the antioxidants production was increased (Helaly et al., 2014).

\section{Conclusion}

Nanoparticles have tendency to enhance the secondary metabolites, antioxidant activities and DPPH radical scavenging capacity. $\mathrm{CuO}$ nanoparticles have proved to have positive effects on secondary metabolites production. Toxicity of nanoparticles affects the growth of callus and produce toxicity in plants. The toxicity pattern of nanoparticles needs to be addressed in different plants.

\section{References}

BHAKUNI, R., JAIN, D., SHARMA, R. and KUMAR, S., 2001. Secondary metabolites of Artemisia annua and their biological activity. Current Science, vol. 80, pp. 35-48.

BUZEA, C., PACHECO, I.I. and ROBBIE, K., 2007. Nanomaterials and nanoparticles: sources and toxicity. Biointerphases, vol. 2, no. 4, pp. MR17-MR71. http://dx.doi.org/10.1116/1.2815690. PMid:20419892.

DEROSA, M.C., MONREAL, C., SCHNITZER, M., WALSH, R. and SULTAN, Y., 2010. Nanotechnology in fertilizers. Nature Nanotechnology, vol. 5, no. 2, pp. 91-91. http://dx.doi.org/10.1038/ nnano.2010.2. PMid:20130583.
DIMKPA, C.O., MCLEAN, J.E., LATTA, D.E., MANANGÓN, E., BRITT, D.W., JOHNSON, W.P., BOYANOV, M.I. and ANDERSON, A.J., 2012. $\mathrm{CuO}$ and $\mathrm{ZnO}$ nanoparticles: phytotoxicity, metal speciation, and induction of oxidative stress in sand-grown wheat. Journal of Nanoparticle Research, vol. 14, no. 9, pp. 1125. http:// dx.doi.org/10.1007/s11051-012-1125-9.

FAKRUDDIN, M., HOSSAIN, Z. and AFROZ, H., 2012. Prospects and applications of nanobiotechnology: a medical perspective. Journal of Nanobiotechnology, vol. 10, no. 1, pp. 31. http://dx.doi. org/10.1186/1477-3155-10-31. PMid:22817658.

FAZAL, H., ABBASI, B.H., AHMAD, N. and ALI, M., 2016. Elicitation of medicinally important antioxidant secondary metabolites with silver and gold nanoparticles in callus cultures of Prunella vulgaris L. Applied Biochemistry and Biotechnology, vol. 180, no. 6, pp. 1076-1092. http://dx.doi.org/10.1007/s12010016-2153-1. PMid:27287999.

FERREIRA, J.F., LUTHRIA, D.L., SASAKI, T., \& HEYERICK, A., 2010. Flavonoids from Artemisia annua L. as antioxidants and their potential synergism with artemisinin against malaria and cancer. Molecules, vol. 15, no. 5, 3135-70.

GHASEMI, B., HOSSEINI, R. and DEHGHAN NAYERI, F., 2015. Effects of cobalt nanoparticles on artemisinin production and gene expression in Artemisia annua. Turkish Journal of Botany, vol. 39, no. 5, pp. 769-777. http://dx.doi.org/10.3906/bot-1410-9.

GIRALDO, J.P., LANDRY, M.P., FALTERMEIER, S.M., MCNICHOLAS, T.P., IVERSON, N.M., BOGHOSSIAN, A.A., REUEL, N.F., HILMER, A.J., SEN, F., BREW, J.A. and STRANO, M.S., 2014. Plant nanobionics approach to augment photosynthesis and biochemical sensing. Nature Materials, vol. 13, no. 4, pp. 400-408. http://dx.doi.org/10.1038/nmat3890. PMid:24633343.

HELALY, M.N., EL-METWALLY, M.A., EL-HOSEINY, H., OMAR, S.A. and EL-SHEERY, N.I., 2014. Effect of nanoparticles on biological contamination of in vitro cultures and organogenic regeneration of banana. Australian Journal of Crop Science, vol. 8, no. 4, pp. 612.

HORIE, M., NISHIO, K., KATO, H., FUJITA, K., ENDOH, S., NAKAMURA, A., MIYAUCHI, A., KINUGASA, S., YAMAMOTO, K., NIKI, E., YOSHIDA, Y., HAGIHARA, Y. and IWAHASHI, H., 2011. Cellular responses induced by cerium oxide nanoparticles: induction of intracellular calcium level and oxidative stress on culture cells. Journal of Biochemistry, vol. 150, no. 4, pp. 461-471. http://dx.doi.org/10.1093/jb/mvr081. PMid:21693544.

JATTANA, A., KIJWIJAN, B., BODHIPADMA, K. and LEUNG, D., 2008. Indirect somatic embryogenesis and synthetic seed production from cotyledon explants of papaya (Carica papaya L.) 'Kaedum'. Journal of Applied Sciences (Faisalabad), vol. 7, pp. 116-122

KHODAKOVSKAYA, M., DERVISHI, E., MAHMOOD, M., XU, Y., LI, Z., WATANABE, F. and BIRIS, A.S., 2009. Carbon nanotubes are able to penetrate plant seed coat and dramatically affect seed germination and plant growth. ACS Nano, vol. 3, no. 10, pp. 3221-3227. http://dx.doi.org/10.1021/nn900887m. PMid:19772305.

KLAYMAN, D.L., 1985. Qinghaosu (artemisinin): an antimalarial drug from China. Science, vol. 228, no. 4703, pp. 1049-1055. http://dx.doi.org/10.1126/science.3887571. PMid:3887571.

LIU, W.-T., 2006. Nanoparticles and their biological and environmental applications. Journal of Bioscience and Bioengineering, vol. 102, no. 1, pp. 1-7. http://dx.doi.org/10.1263/jbb.102.1. PMid:16952829. 
NAIR, R., VARGHESE, S.H., NAIR, B.G., MAEKAWA, T., YOSHIDA, Y. and KUMAR, D.S., 2010. Nanoparticulate material delivery to plants. Plant Science, vol. 179, no. 3, pp. 154-163. http://dx.doi.org/10.1016/j.plantsci.2010.04.012.

OLOUMI, H., SOLTANINEJAD, R. and BAGHIZADEH, A., 2015. The comparative effects of nano and bulk size particles of $\mathrm{CuO}$ and $\mathrm{ZnO}$ on glycyrrhizin and phenolic compounds contents in Glycyrrhiza glabra L. seedlings. Indian Journal of Plant Physiology / Official Publication of the Indian Society for Plant Physiology, vol. 20, no. 2, pp. 157-161. http://dx.doi.org/10.1007/ s40502-015-0143-x.

ROCO, M.C., 2003. Nanotechnology: Convergence with modern biology and medicine. Current Opinion in Biotechnology, vol. 14, no. 3, pp. 337-346. http://dx.doi.org/10.1016/S0958-1669(03)000685. PMid: 12849790.

SANCHEZ, F. and SOBOLEV, K., 2010. Nanotechnology in concrete-a review. Construction \& Building Materials, vol. 24, no. 11, pp. 2060-2071. http://dx.doi.org/10.1016/j. conbuildmat.2010.03.014.
SCRINIS, G. and LYONS, K., 2007. The emerging nano-corporate paradigm: nanotechnology and the transformation of nature, food and agri-food systems. International Journal of Sociology of Agriculture and Food, vol. 15, no. 2, pp. 22-44.

SHARMA, P., BHATT, D., ZAIDI, M., SARADHI, P.P., KHANNA, P. and ARORA, S., 2012. Silver nanoparticle- mediated enhancement in growth and antioxidant status of Brassica juncea. Applied Biochemistry and Biotechnology, vol. 167, no. 8, pp. 2225-2233. http://dx.doi.org/10.1007/s12010-012-9759-8. PMid:22692847.

ZHANG, B., ZHENG, L.P., YI LI, W. and WEN WANG, J., 2013. Stimulation of artemisinin production in Artemisia annua hairy roots by Ag-SiO2 core-shell nanoparticles. Current Nanoscience, vol. 9, no. 3, pp. 363-370. http://dx.doi.org/10.2174/15734137 11309030012 .

ZHAO, J., DAVIS, L.C. and VERPOORTE, R., 2005. Elicitor signal transduction leading to production of plant secondary metabolites. Biotechnology Advances, vol. 23, no. 4, pp. 283-333. http://dx.doi.org/10.1016/j.biotechadv.2005.01.003. PMid:15848039. 